\title{
TFIIH Basal Transcription Factor Complex Helicase XPB Subunit
}

National Cancer Institute

\section{Source}

National Cancer Institute. TFIIH Basal Transcription Factor Complex Helicase XPB

Subunit. NCI Thesaurus. Code C21452.

TFIIH basal transcription factor complex helicase XPB subunit (782 aa, $89 \mathrm{kDa}$ ) is encoded by the human ERCC3 gene. This protein is involved in RNA polymerase IImediated transcription, DNA helicase activity and nucleotide excision repair. 